\title{
The Effect of Psychological Capital on Motivation for Individual Instrument: A Study on University Students
}

\author{
Dilek Özçelik Herdem
}

Faculty of Education, Gazi University, Turkey

Copyright $\subseteq 2019$ by authors, all rights reserved. Authors agree that this article remains permanently open access under the terms of the Creative Commons Attribution License 4.0 International License

\begin{abstract}
This study aims to investigate the effect of psychological capital of undergraduate students on the motivation for individual instrument. In the study, survey method was used as data collection method. The sample of the research consisted of 214 students attending Gazi University and Hac1 Bayram Veli University located in Ankara. SPSS and AMOS software programs were employed to analyze data. Confirmatory factor analysis was performed for the validity of the scale, and Cronbach Alpha was computed to test the reliability. In the study, descriptive statistics were displayed, and independent sample t-test as well as one-way analysis of variance (ANOVA) was used to identify the differences according to university, gender, and class. Structural equation model was established to test the hypothesis. Regression analysis indicates that resilience significantly and positively affects motivation for achievement.
\end{abstract}

Keywords Motivation for Individual Instrument, Psychological Capital, Music Education

\section{Introduction}

Motivation is impulsive force that directs the individual to personal goals by internal motives in compliance with personal demands and needs [1]. Likewise, motivation is cognitive power or internal energy that supports the self to achieve the goals [2]. Or motivation is a driving force to initiate and sustain an action. On the other hand, amotivation is lacking intention to move [3]. In other words, it is the lack of motivation. Then amotivation is not benefiting from an action or not feeling self-efficacy to do the action.

An individual, therefore, focuses on the action, behaves as planned, and easily finds solutions to problems when motivated. To this end, it is not wrong to say that individual is expected to create intrinsic motivation to initiate an action. In other words, it is not true to await being motivated by others.

The state defined above is also valid through education years. Students having intrinsic motivation feel satisfied when they study. It is of great significance that the students have intrinsic motivation and does whatever they do with great satisfaction. On the other hand, some may not have motivation for study. Concerning the students with lower intrinsic motivation, teachers may develop themselves to employ some strategies to motivate the students having extrinsic motivation.

Considering students, motivation is the starting point for a student to learn a lesson, an incentive to move, and contributes them to finalize whatever they started doing during the study years [4]. Because instrument playing education takes long hours and requires high physical performance as well as psychological performance, having the will to act is one of main factors to develop performance skills in playing an instrument as a part of music education.

It may be contended that every process contributing to achieve personal goals requires motivation-either intrinsic or extrinsic. To this end, we may advocate that intrinsic motivation is nontrivial for the students during their university years. Thus, it is critical to study the determinants of motivation of students related to their study areas. That's why this study aims to determine the effect of psychological capital on motivation for individual instrument. Another importance of the study is that the role of psychological capital in academia is attached limited attention [5].

The rest of the study is designed as follows: the following chapter is on the concepts and the relation between concepts in order to develop the study's hypothesis. Next, we introduce the methodology including model, sample and scales. Findings are thoroughly discussed in the fourth chapter. The study concludes with discussion and recommendations. 


\section{Theoretical Framework}

\subsection{Motivation for Individual Instrument}

Motivation is the process of prompting and directing oneself for achieving personal goals [6]. Indeed, motivation may be seen as an improved version of self-influence theory once it is also considered as internal energy supporting individuals to achieve desired goal or cognitive power helping them to reach the goals [2]. Likewise, behavioral approach suggests that positive experiences and rewards are main incentives for students to succeed in personal goals [7]. Similarly, according to Bandura, pioneer of social learning theory, motivation for the students will be high if they expect positive results [8]. On the other hand, Maslow as a humanistic approach representative states that requirements are ordered and satisfied in order to meet the individual's needs. But motivation is not only a success but also a collection of will, effort, and attitudes [9].

There is a plenty of studies discussing literature on motivation. However, literature is not definite on types of motivation. To our best understanding, there are five types of approaches on motivation for learning; natural interest, external resources, success, self-esteem, and feedback [10]. On the other hand, Gardner and Lambert [11] mentions two types of motivation as inclusive and instrumental.

In general, Deci and Ryan [3] create motivation types in self-determination theory, focusing the causes to lead the action; namely, intrinsic motivation, extrinsic motivation, and amotivation. The one with intrinsic motivation acts because of satisfaction of doing something interesting or enjoyable whereas the one with extrinsic motivation acts because of the outcomes acquired in the end. And amotivation is the lack of motivation. While intrinsic motivation is related to self-determination, competence, task involvement, curiosity, enjoyment, and interest, extrinsic motivation concerns with competition, evaluation, recognition, money or other tangible incentives, and constraint by others [12].

Deci and Ryan [3] categorize intrinsic motivation into three groups. First is related to cognition. Intrinsic motivation related to cognition includes action due to satisfaction while learning new things. This type of intrinsic motivation is the most important part of effective learning and higher achievement. Second type is intrinsic motivation for achievement. This type of intrinsic motivation means satisfaction of successfully completing the action and creating new things. Third and last type of intrinsic motivation is the one for stimulation. Intrinsic motivation for stimulation indicates the behaviors to stimulate and excite.

Similarly, extrinsic motivation is grouped as identification, introjection, and external regulation. Identification is the process that individuals transform regulations into their own interest and personal significance. It is also the most autonomous one among extrinsic motivation types, as well. Introjection makes individuals act with the feeling of avoiding guilt or anxiety. In addition to two, external regulation is used to explain the behavior based on an extrinsic demand or a reward.

\subsection{Psychological Capital}

Positive psychology is first introduced to the literature as a positive science on personal positive experiences and characteristics [13]. Mission of psychology is not only helping the mentally ill but also guiding people being more productive and satisfied [14]. Indeed, positive psychology is a paradigm shift focuses on personal characteristics to be developed [15]. It is a multi-disciplined holistic approach including all perspectives contributing to an individual's subjective well-being [16]. To this end, we may define positive psychology as an individual's positively psychological developmental state [17].

In this regard, psychological capital researches the question "Who am I?" [18]. Thus, psychological capital is defined as a tool to minimize the negative effects of environmental factors and to improve human resources [19, 20]. This means a shift from thinking "what's wrong with people" to "what's right with people" [21-23]. That's why, psychological capital focuses on subjective well-being due to past time, hope and positivism about future, and happiness because of the time being [24].

Luthans and his colleagues who introduced psychological capital mentions a four sub-factor structure and listed them as self-efficacy, positivism, hope, and resilience [20]. Self-efficacy is self-confidence of the one to cope with challenges $[17,20,25]$. In other words, self-efficacy is the belief on the capacity of the one to get successful results [7]. According to Luthans, Youssef and Avolio [26], self-efficacy changes with performance and experience. Some characteristics of individuals with higher self-efficacy prefer challenging goals, coping with hurdles, self-motivating, and exert sufficient effort to reach the goals [26].

Positivism, second factor, is about positive attitudes of an individual to succeed now and then [17-19, 25]. A positivist does not generalize the events and believes in that happenings may change over time [27]. A positive individual is good at coping strategies and problem-solving related to interpersonal relations [28].

Third subfactor of psychological capital is called as resilience. Strong state demonstrated by an individual to succeed by confronting problems is named as resilience [17, $20,25]$. Even when an individual is surrounded by negative events, resilience means continuing for success following recoveries each time [18].

Hope, the fourth factor, is an individual's will for a desired end state while producing alternative routes and choosing the best to reach the desired end state [25]. Hope is definitely goal-oriented energy and comprises the 
capacity of producing alternatives $[29,30]$. Then, hope is related with meaning of life, subjective wellbeing, self-confidence, and resilience [31]. Moreover, hope is basic state of a person including belief and trust towards the world, i.e. thought about the value of life [32].

\subsection{Hypothesis Development}

Because human capital is becoming more significance for organizations, there is an ever growing interest on psychological capital [33]. However, there are some limited studies related to students. For instance, relation between psychological capital and entrepreneurship orientation of students was researched by Yalçın [34]. Psychological capital of university students in the context of career adaptability was investigated by Mercan [35]. The differences among students' psychological capital according to demographic variables were explained by İştar Işıklı [36]. The relationship between psychological capital and life satisfaction was found out [37]. The impact of business school students' psychological capital on academic performance was identified [38, 39]. Psychological capital was found as a buffer to student stress [40]. The studies highlight the importance of psychological capital on students' academic achievement and personal goals.

Higher psychological capital leads to higher self-confidence, setting goals, seeking ways to become better teachers, and believing in that future brings positive states for their organizations [41]. Thus it is not wrong to say that psychological capital fosters motivation [5]. A longitudinal study [42] reveals that psychological capital increases intrinsic motivation even though it decreases in time. Also, a training on psychological capital contributes to participants' both personal and professional development [43].

There are also other researches focusing the relations among sub-factors of both variables. For instance; individuals with higher self-efficacy have a higher intrinsic motivation [44]. According to a research on the relation between psychological capital and motivation, there is significant and positive relation between hope and extrinsic motivation [45]. Hope is one of determinants of positive and successful coping strategies [46, 47]. The persons having hope use intrinsic and extrinsic motivation resources effectively; thus keep their activeness while they achieve the goals [48].

There is a significant relation between resilience and life satisfaction and hope partially plays a mediating role in this relationship [49]. Intrinsic motivation is a significant mediator between psychological capital of students and their study engagement [50]. Similarly, another study underlines the importance of intrinsic motivation in the relation between psychological capital and job satisfaction [51]. According to methodology of mediation, there must be an interaction between psychological capital and motivation.

According to the discussions above, we may end up that students with higher psychological capital know their goals thus are motivated to study. Thus, we may develop the hypothesis as follows:

H1: There is a significant and positive effect of psychological capital on motivation for individual instrument.

In the following part of the study, the sample of the study and information about participants, measurement tools employed in the research, the analyses, and the findings are discussed respectively.

\section{Research Method}

\subsection{Study Group}

There are 156 students enrolled in Music Education Division in the Faculty of Education in Gazi University. Similarly, there are 135 students enrolled in Ankara Hac1 Bayram Veli University. All students in both universities were asked for completing the survey form, but 214 of the students returned the questionnaires. In this case, the return rate was $73.54 \%$. The number of the sample at the significance level of $5 \%$ with a confidence interval of $5 \%$ is determined as 166 [52]. Hence, the sample is adequate to represent the population. Descriptive statistics regarding demographic variables are given in the following tables.

The frequency distribution of the university at which the students study is given in Table 1. While $126(58.9 \%)$ of the students study in Gazi University (GU), 88 (41.1\%) of the students study in Ankara Hacı Bayram Veli University (AHBVU).

Table 1. Universities of Students

\begin{tabular}{|l|c|c|c|}
\hline & Frequency & $\%$ & Cumulative \% \\
\hline Gazi University (GU) & 126 & 58,9 & 58,9 \\
\hline $\begin{array}{l}\text { Ankara Haci Bayram Veli } \\
\text { University (AHBVU) }\end{array}$ & 88 & 41,1 & 100,0 \\
\hline Total & 214 & 100,0 & \\
\hline
\end{tabular}

The frequency of the students regarding gender is given in Table 2. 114 of the students are male $(53,3 \%)$ while 100 of the students are female $(46,7 \%)$.

Table 2. Students' Gender

\begin{tabular}{|c|c|c|c|}
\hline & Frequency & $\%$ & Cumulative \% \\
\hline Male & 114 & 53,3 & 53,3 \\
\hline Female & 100 & 46,7 & 100,0 \\
\hline Total & 214 & 100,0 & \\
\hline
\end{tabular}

The frequency of the students related to class is given in Table 3. The number of freshman is $52(24,3 \%)$, the number of sophomore is $58(27,1 \%)$, the number of middler is $55(25,7 \%)$, and that of senior is $49(22,9 \%)$. 
Table 3. Students' Classes

\begin{tabular}{|l|c|c|c|}
\hline & Frequency & $\%$ & Cumulative \% \\
\hline Freshman & 52 & 24,3 & 34,4 \\
\hline Sophomore & 58 & 27,1 & 58,1 \\
\hline Middler & 55 & 25,7 & 82,9 \\
\hline Senior & 49 & 22,9 & 100,0 \\
\hline Total & 214 & 100,0 & \\
\hline
\end{tabular}

\subsection{Questionnaire}

Data on demographic information, psychological capital, and motivation for individual instrument were gathered through a self-reported questionnaire. Validity and reliability studies of adapted psychological capital scale in a student sample were previously made by Yalçın [34]. Psychological capital was first introduced by Luthans and his colleagues [43]. The scale consists of 24 items to measure four different factors. The first 6 items measure resilience, next 6 measures hope, following 6 measures self-efficacy and the rest 6 measures positivism. 3 items ( 7 , $20,23)$ are reverse coded; hence, these items transformed into the usual coding, then analysis was went on.

Validity and reliability of motivation for individual instrument scale was conducted by Girgin [53]. As a result of exploratory factor analysis, the researcher concluded that the scale consist of 25 items with a 3 factor model. Subfactors were called amotivation, motivation for achievement, and motivation for study, respectively. 5 -point Likert scale was preferred in the questionnaire and participants were asked to mark to what extent they agree with the statements given ( $1=$ Totally disagree, $2=$ Disagree, $3=$ No idea, $4=$ Agree, $5=$ Totally agree).

In this study, the construct validity was analyzed by confirmatory factor analysis (CFA) and Cronbach Alpha coefficient was employed to test the reliability. CFA results are shown in Table 4, and the results of the reliability analysis are given in Table 5. When the CFA results of psychological capital are examined, it is observed that the fit index values of the tested models are not within acceptable limits [54]. Therefore, modification indices are thoroughly examined. By subtracting question numbered 13 from psychological capital scale, second level related model is modified. Thus the fit index values of the scale became within acceptable limits.

The fit index values of the scale are given in Table 4 $\left(\chi^{2} /\right.$ s.d. $=2,008 ; \mathrm{RMR}=0,076 ; \mathrm{IFI}=0,915 ; \mathrm{TLI}=0,900 ;$ $\mathrm{CFI}=0,914 ; \mathrm{RMSEA}=0,069 ; \mathrm{p}=0,000)$. In this case, the results of reliability analysis of psychological capital scale, in general, based on size and factor, were obtained as shown in Table 5. When the validity and reliability analysis of the psychological capital scale are considered together, it is understood that it is more appropriate to consider the scale as related multi-factor in this study. Because, according to CFA, the second level related model was confirmed, and the Cronbach's alpha of the scale was found as 0,913 and subfactors were deemed reliable (Table 5).

Similarly, the second-level related model for motivation for individual instrument scale is shown in Figure 1. CFA results are shown in Table 6 , and the results of the reliability analysis are given in Table 7 . When the CFA results of the motivation for individual instrument are examined, it is observed that the fit index values of the models are not within acceptable limits [54]. Therefore, modification indices are thoroughly examined. By subtracting questions numbered 1,24, and 26 from the self-leadership scale, the model is modified. Thus the fit index values of the scale became within acceptable limits. The modified second-level related model of motivation for individual instrument scale is given in Figure 1. The fit index values of the scale are given in Table $6\left(\chi^{2} / \mathrm{s}\right.$.d. $=$ 2,$315 ; \mathrm{RMR}=0,068 ; \mathrm{IFI}=0,927$; TLI $=0,917$; CFI $=$ 0,927 ; RMSEA $=0,079 ; \mathrm{p}=0,000$ ).

Table 4. Psychological Capital Scale CFA Results

\begin{tabular}{|l|c|c|c|c|c|c|c|c|}
\hline & $\chi^{2}$ & d.f. & $\chi 2 /$ d.f. & RMR & IFI & TLI & CFI & RMSEA \\
\hline First Level One Factor Model & 1154,891 & 252 & 4,583 & 0,101 & 0,675 & 0641 & 0672 & 0,130 \\
\hline Second Level Unrelated Model & 1002,408 & 252 & 3,978 & 0,263 & 0,730 & 0,702 & 0,728 & 0,118 \\
\hline Second Level Related Model & 684,244 & 246 & 2,781 & 0,092 & 0,843 & 0,821 & 0,841 & 0,091 \\
\hline Second Level Multi-Factor Model & 739,924 & 249 & 2,972 & 0,240 & 0,823 & 0,802 & 0,822 & 0,096 \\
\hline Modified Model & 435,685 & 217 & 2,008 & 0,076 & 0,915 & 0,900 & 0,914 & 0,069 \\
\hline
\end{tabular}

$\chi^{2}$ : Chi-square; d.f.: degree of freedom; RMR: root mean square residual; IFI: Bollenments Incremental Fit Index; TLI: Tucker-Lewis Index; CFI: Bentler Comparative Fit Index; RMSEA Root Mean Square Error of Approximation.

Table 5. Psychological Capital Scale Reliability Analysis Result

\begin{tabular}{|c|c|c|c|c|}
\hline General & Resilience & Hope & Self-efficacy & Positivism \\
\hline 0,913 & 0,834 & 0,856 & 0,875 & 0,686 \\
\hline
\end{tabular}


Table 6. Individual Motivation Scale CFA Results

\begin{tabular}{|l|c|c|c|c|c|c|c|c|}
\hline & $\chi^{2}$ & s.d. & $\chi^{2} / \sigma . \delta$. & RMR & IFI & TLI & CFI & RMSEA \\
\hline One Factor Model & 2323,116 & 275 & 8,448 & 0,143 & 0,570 & 0,529 & 0,568 & 0,187 \\
\hline Second Level Unrelated Model & 1172,014 & 275 & 4,262 & 0,269 & 0812 & 0,794 & 0,811 & 0,124 \\
\hline Second Level Related Model & 1024,558 & 272 & 3,767 & 0,072 & 0,842 & 0,825 & 0,841 & 0,114 \\
\hline Second Level Multi-Factor Model & 1056,004 & 273 & 3,868 & 0,125 & 0,836 & 0,818 & 0,835 & 0,116 \\
\hline Modified Model & 611,132 & 264 & 2,315 & 0,068 & 0,927 & 0,917 & 0,927 & 0,079 \\
\hline
\end{tabular}

$\chi^{2}$ : Chi-square; d.f.: degree of freedom; RMR: root mean square residual; IFI: Bollenments Incremental Fit Index; TLI: Tucker-Lewis Index; CFI: Bentler Comparative Fit Index; RMSEA Root Mean Square Error of Approximation.

In this case, the results of reliability analysis of motivation for individual instrument scale, in general, based on size and factors were obtained as shown in Table 7. When the validity and reliability analysis of motivation for individual instrument scale are considered together, it is understood that it is more appropriate to consider motivation for individual instrument as related model in this study. Because, according to CFA, the second level multifactorial structure was confirmed. In addition, when the reliability analysis results in Table 7 are examined, scale as a whole had low reliability in comparison with the subfactors.

Table 7. Motivation for individual instrument Scale Reliability Analysis Result

\begin{tabular}{|c|c|c|c|}
\hline General & Amotivation & $\begin{array}{c}\text { Motivation for } \\
\text { Achievement }\end{array}$ & $\begin{array}{c}\text { Motivation for } \\
\text { Study }\end{array}$ \\
\hline 0,691 & 0,951 & 0,924 & 0,891 \\
\hline
\end{tabular}

\section{Findings}

\subsection{Descriptive Statistics and Tests for Differences}

After the validity and reliability studies of the scales employed in the study were completed, hypothesis tests were conducted to verify the research hypotheses. To test the differences, mean of the scales as a whole and subfactors were computed. Descriptive statistics regarding the scales are displayed in Table 8. Regarding psychological capital, resilience and self-efficacy have the greatest mean while hope and positivism are lower, respectively. However, all subfactors of psychological capital is over average. Considering motivation for individual instrument, motivation for achievement has the highest average whereas amotivation has the lowest mean.

Independent sample t-test and one-way analysis of variance (ANOVA) were employed in the study to investigate whether psychological capital and motivation for individual instrument of the students differ by demographic factors. Independent sample t-test was employed to determine the difference by university and gender while ANOVA was employed to determine the difference by class. The results of the hypotheses tests to determine whether psychological capital and motivation for individual instrument of the students differ by students' class, university, and gender are listed in the following tables respectively.

The results of one way ANOVA to determine whether psychological capital and motivation for individual instrument of students differ by the classes are given in Table 9. The rest of subfactors of the variables are excluded in the table since their significance is greater than 0,05 . When Table 9 is examined, it can be seen that students' perceptions of resilience and motivation for achievement significantly differ according to their classes. Post-hoc analysis was made to determine which classes differ. At first, homogeneity of variances was tested, and it was assumed that the variances were not equal (Levene statistical value for resilience $=1,183 ; \mathrm{p}=0,387$; Levene statistical value for motivation for achievement $=1,141$; $\mathrm{p}=0,333$ ). To this end, Games Howell test was preferred as Post-Hoc analysis method and differences among groups were determined by means of further analysis and shown in Table 9.

Regarding resilience, perceptions of the freshman (mean $=4,07$, s.d. $=0,578)$ are significantly greater than sophomore (mean $=3,71$, s.d. $=0,654$ ). It is clear that first class of music education require hard working and orientation following high school need some strong state to confront problems. Regarding motivation for achievement, perceptions of the freshman (mean $=4,56$, s.d. $=0,558)$ are significantly greater than senior ( $m e a n=4,15$, s.d. $=0,790$ ). There is a declining trend for the motivation for achievement through the first class to the last. Skill development may replace academic achievement in parallel with growing university years. 
Table 8. Descriptive Statistics

\begin{tabular}{|l|c|c|c|c|c|}
\hline & $\mathrm{N}$ & Minimum & Maximum & Mean & Std. Deviation \\
\hline Psychological Resilience & 214 & 1,00 & 5,00 & 3,88 & 0,69 \\
\hline Hope & 214 & 1,00 & 5,00 & 3,69 & 0,69 \\
\hline Self-efficacy & 214 & 1,00 & 5,00 & 3,89 & 0,75 \\
\hline Positivism & 214 & 1,00 & 5,00 & 3,43 & 0,71 \\
\hline Amotivation & 214 & 1,00 & 5,00 & 1,54 & 0,78 \\
\hline Motivation for Achievement & 214 & 1,00 & 5,00 & 4,37 & 0,73 \\
\hline Motivation for Study & 214 & 1,00 & 5,00 & 3,40 & 0,95 \\
\hline
\end{tabular}

Table 9. Results of ANOVA

\begin{tabular}{|c|c|c|c|c|c|c|c|}
\hline & Student's Classes & $\mathrm{N}$ & Mean & s.d. & Differentiation & $\mathrm{F}$ & $\mathrm{p}$ \\
\hline \multirow{5}{*}{ Resilience } & Freshman & 52 & 4,07 &, 578 & Sophomore & \multirow{5}{*}{2,654} & \multirow{5}{*}{,050 } \\
\hline & Sophomore & 58 & 3,71 & 654 & Freshman & & \\
\hline & Middler & 55 & 3,92 &, 829 & --- & & \\
\hline & Senior & 49 & 3,84 & ,638 & --- & & \\
\hline & Total & 214 & 3,88 & 691 & & & \\
\hline \multirow{5}{*}{ Motivation for Achievement } & Freshman & 52 & 4,56 &, 558 & Senior & \multirow{5}{*}{2,765} & \multirow{5}{*}{, 043} \\
\hline & Sophomore & 58 & 4,42 & ,752 & --- & & \\
\hline & Middler & 55 & 4,33 & ,786 & --- & & \\
\hline & Senior & 49 & 4,15 & ,790 & Freshman & & \\
\hline & Total & 214 & 4,37 &, 737 & & & \\
\hline
\end{tabular}

Table 10. Perceptions of Students According to University

\begin{tabular}{|c|c|c|c|c|}
\hline & University & $\mathrm{N}$ & Mean & s.d. \\
\hline \multirow{2}{*}{ Resilience* } & GU & 126 & 3,80 &, 732 \\
\hline & AHBVU & 88 & 3,99 & ,616 \\
\hline \multirow{2}{*}{ Self-efficacy* } & GU & 126 & 3,61 &, 747 \\
\hline & AHBVU & 88 & 3,81 & ,600 \\
\hline \multirow{2}{*}{ Hope } & $\mathrm{GU}$ & 126 & 3,83 & ,787 \\
\hline & AHBVU & 88 & 3,97 &, 712 \\
\hline \multirow{2}{*}{ Positivism* } & $\mathrm{GU}$ & 126 & 3,34 & ,731 \\
\hline & AHBVU & 88 & 3,55 & ,684 \\
\hline \multirow{2}{*}{ Amotivation } & GU & 126 & 1,58 &, 845 \\
\hline & AHBVU & 88 & 1,47 & 699 \\
\hline \multirow{2}{*}{$\begin{array}{l}\text { Motivation for } \\
\text { Achievement }\end{array}$} & GU & 126 & 4,34 & 676 \\
\hline & AHBVU & 88 & 4,41 & 820 \\
\hline \multirow{2}{*}{ Motivation for Study } & GU & 126 & 3,32 & ,900 \\
\hline & AHBVU & 88 & 3,50 & 1,018 \\
\hline
\end{tabular}

$* \mathrm{p}<0,05$

Perceptions of students according to psychological capital and motivation for individual instrument regarding universities enrolled were tested by means of independent sample t-test to determine whether they differ by the university. Results of independent sample t-test are given in Table 10. When the table is examined, it is seen that motivation for individual instrument does not differ by university students enrolled. However, all subfactors of psychological capital, except hope, significantly differ by the university. Regarding resilience, perceptions of the students attending AHBVU (mean=3,99, s.d.=0,616) are significantly greater than the ones attending $\mathrm{GU}$ (mean $=3,80$, s.d. $=0,732$ ). Likewise, regarding self-efficacy, perceptions of the students attending AHBVU (mean=3,81, s.d. $=0,600)$ are significantly greater than the ones attending GU (mean=3,61, s.d. $=0,747$ ). In a similar vein, regarding positivism, perceptions of the students attending AHBVU (mean $=3,55$, s.d. $=0,684)$ are significantly greater than the ones attending $\mathrm{GU}$ (mean=3,34, s.d.=0,731). It is difficult to discuss the results according to university without additional information, in particular organizational factors. Nonetheless, fresh start of AHBVU in 2018 may be a significant factor for the students to differentiate the perceptions of resilience, self-efficacy, and positivism. Moreover, students studying at GU are music teacher candidates whereas the ones at conservatoire at AHBVU are on the way to be artists. Difference in tracks may create difference of the perceptions

Perceptions of students related to psychological capital and motivation for individual instrument according to gender are tested by means of independent sample t-test to determine whether they differ by gender. Results of independent sample t-test are given in Table 11. When the table is examined, it is seen that psychological capital does not differ by gender. On the other side, amotivation significantly differs by gender that perceptions of female students (mean $=1,41$, s.d. $=0,616)$ are significantly lower 
than the males (mean $=1,64$, s.d. $=0,825)$.

Table 11. Perceptions of Students According to Gender

\begin{tabular}{|l|c|c|c|c|}
\hline \multirow{2}{*}{ Resilience } & Gender & $\mathrm{N}$ & Mean & s.d. \\
\hline \multirow{2}{*}{ Self-efficacy } & Male & 114 & 3,87 &, 710 \\
\cline { 2 - 5 } & Female & 100 & 3,89 &, 673 \\
\hline \multirow{2}{*}{ Hope } & Male & 114 & 3,67 &, 717 \\
\cline { 2 - 5 } & Female & 100 & 3,72 &, 680 \\
\hline \multirow{2}{*}{ Positivism } & Male & 114 & 3,92 &, 732 \\
\cline { 2 - 5 } & Female & 100 & 3,86 &, 791 \\
\hline \multirow{2}{*}{ Amotivation* } & Male & 114 & 3,40 &, 764 \\
\cline { 2 - 5 } & Female & 100 & 3,46 &, 664 \\
\hline \multirow{2}{*}{ Motivation for Achievement } & Male & 114 & 1,64 &, 825 \\
\cline { 2 - 5 } & Female & 100 & 1,41 &, 729 \\
\cline { 2 - 5 } & Male & 114 & 4,29 &, 763 \\
\hline \multirow{2}{*}{ Motivation for Study } & Male & 100 & 4,46 &, 700 \\
\cline { 2 - 5 } & Female & 100 & 3,50 &, 972 \\
\hline
\end{tabular}

$* \mathrm{p}<0,05$

\subsection{Structural Equation Model and Regression Analysis}

In order to test the research hypothesis, second-level related models of psychological capital and motivation for individual instrument was used to form structural equation model (SEM) and to run regression analysis to identify the relations among the variables. SEM is shown in Figure 1 and fit indices of SEM are shown in Table 12. When the fit indices of SEM are examined, it is observed that the values are not within acceptable limits [54]. Therefore, modification indices are thoroughly examined. By applying modifications as shown in Figure 1, SEM is modified. Thus the fit index values of the scale became within acceptable limits.

Table 12. Fit Indices for SEM

\begin{tabular}{|l|l|l|}
\hline Fit Index & SEM & Modified SEM \\
\hline$\chi^{2}$ & 740,028 & 1800,333 \\
\hline s.d. & 249 & 1035 \\
\hline$\chi^{2} /$ s.d. & 2,972 & 1,739 \\
\hline RMR & 0,240 & 0,073 \\
\hline IFI & 0,823 & 0,901 \\
\hline TLI & 0,802 & 0,891 \\
\hline CFI & 0,822 & 0,900 \\
\hline RMSEA & 0,096 & 0,059 \\
\hline
\end{tabular}

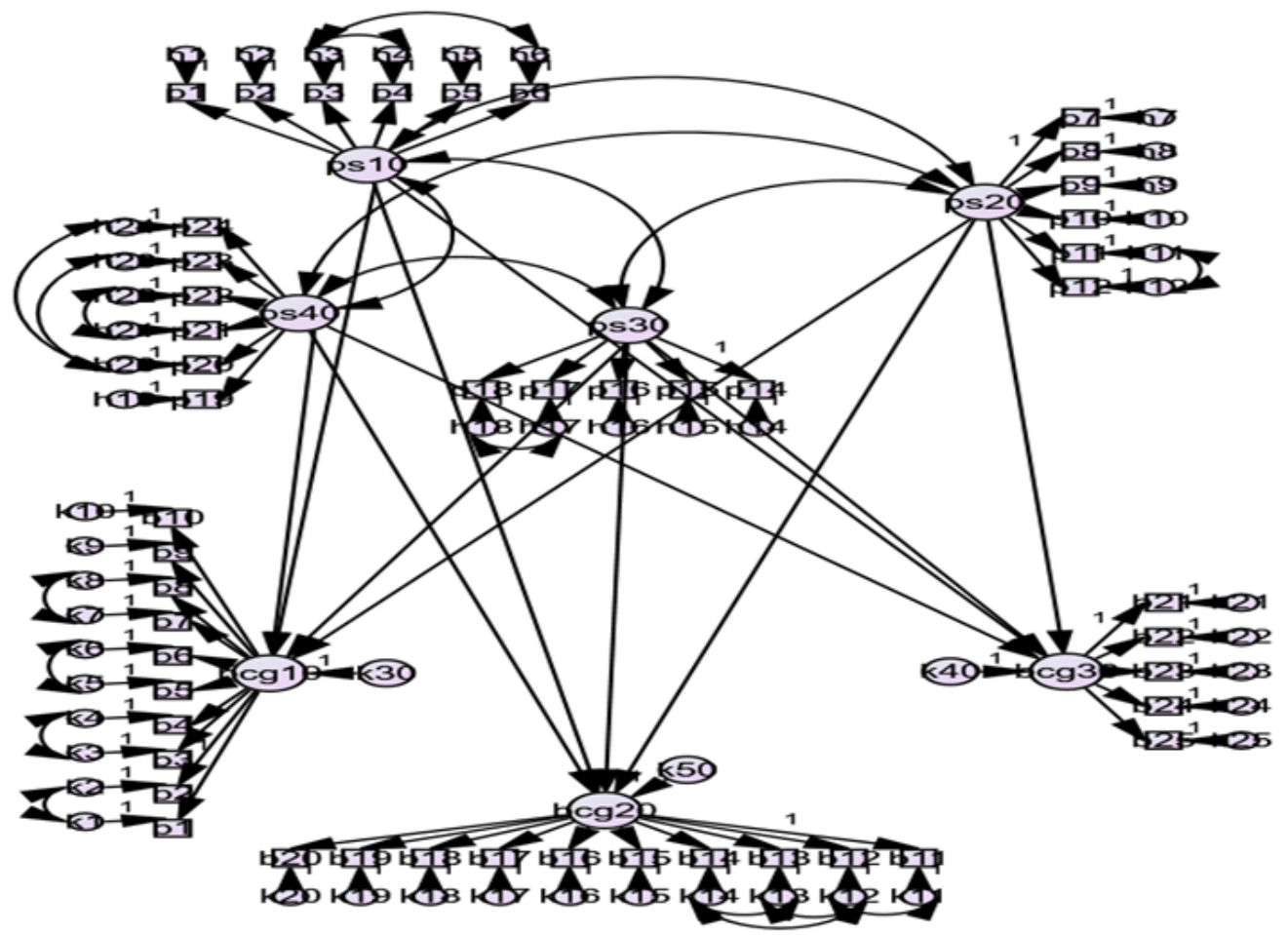

Structural Equation Model (SEM)

Figure 1 (continuing). Structural Equation Model and Regression Analysis 


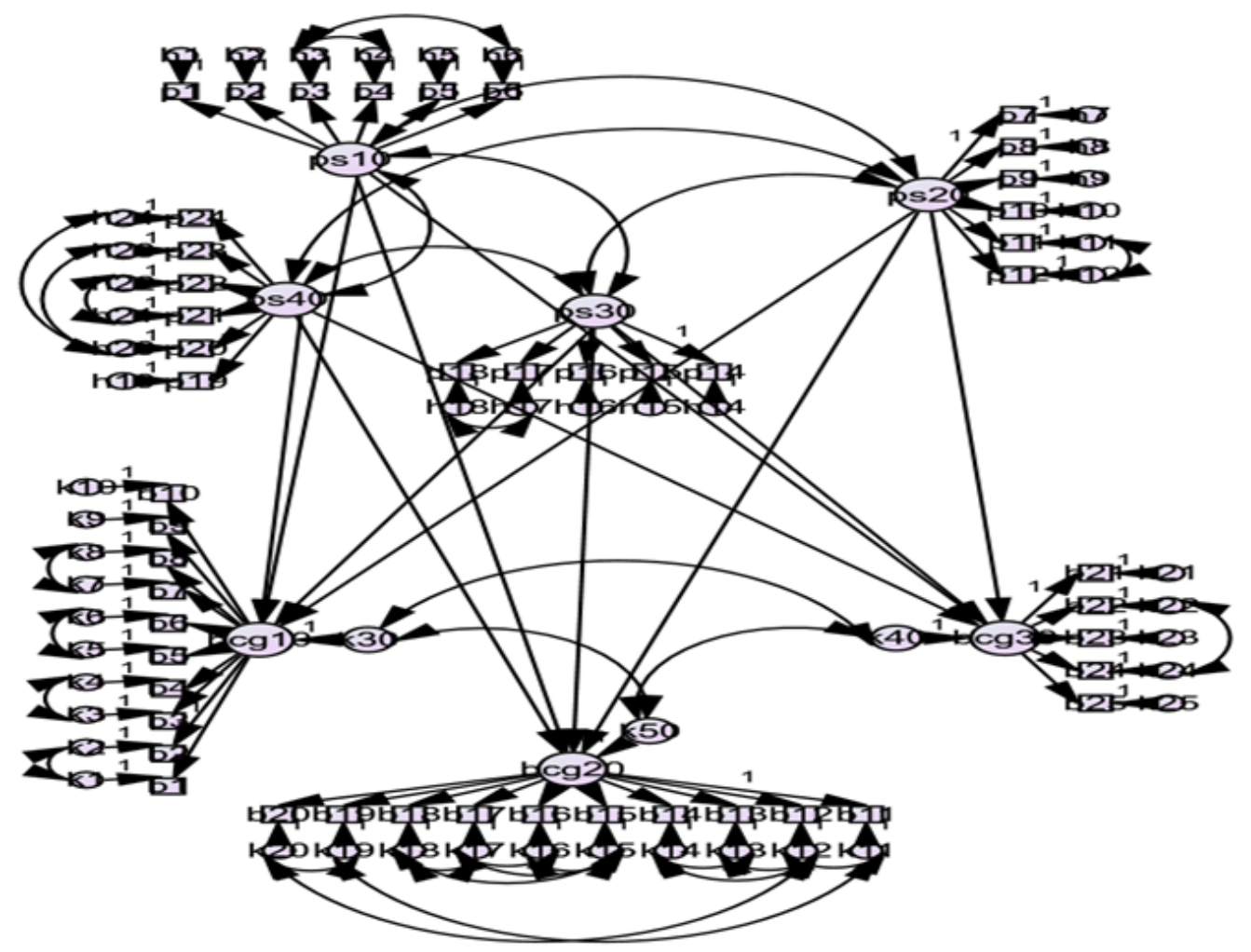

Modified SEM

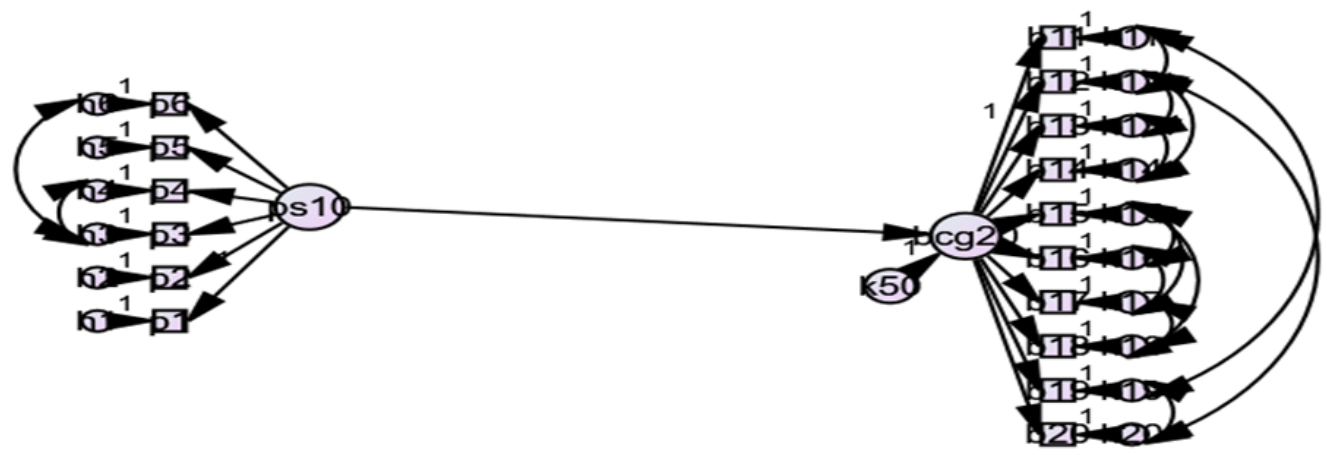

Regression Analysis

Figure 1 (continued). Structural Equation Model and Regression Analysis

Table 13. Regression Analysis

\begin{tabular}{|c|c|c|c|}
\hline & $\beta$ & s.e. & $\mathrm{p}$ \\
\hline Resilience $\rightarrow$ Amotivation &,- 149 &, 145 & ,303 \\
\hline Resilience $\rightarrow$ Motivation for Achievement & ,604 &, 139 & $* * *$ \\
\hline Resilience $\rightarrow$ Motivation for Study & ,317 &, 180 & ,078 \\
\hline Self-efficacy - Amotivation &,- 182 & , 195 & ,351 \\
\hline Self-efficacy $\rightarrow$ Motivation for Achievement & 060 &, 144 & ,680 \\
\hline Self-efficacy $\rightarrow$ Motivation for Study & ,315 & ,242 & ,192 \\
\hline Hope - Amotivation &,- 188 & ,158 & ,232 \\
\hline Hope $\rightarrow$ Motivation for Achievement &,- 002 &, 117 & ,989 \\
\hline Hope $\rightarrow$ Motivation for Study &, 103 & ,191 &, 590 \\
\hline Positivism - Amotivation & 017 & ,105 & ,874 \\
\hline Positivism $\rightarrow$ Motivation for Achievement &,- 057 & 079 & 466 \\
\hline Positivism $\rightarrow$ Motivation for Study &,- 013 & , 128 & 920 \\
\hline
\end{tabular}


Once SEM was modified and confirmed, regression analysis was employed to identify the interactions among subfactors of the variables. Table 13 gives the results of regression analysis. According to results, resilience significantly and positively affects motivation for achievement $(\beta=0,317, p<0,05)$. There are no significant relations among the other variables.

\section{Discussion and Conclusions}

Considering students, motivation is the starting point for a student to learn a lesson, an incentive for a student to move, and contributes them to finalize whatever they started doing during the study years [4]. It is renowned and of great significance in education that the students have intrinsic motivation and does whatever they do with great satisfaction. On the other hand, concerning the students with lower intrinsic motivation, teachers may develop themselves to employ some strategies to motivate the students having extrinsic motivation. Because instrument playing education takes long hours and requires high physical performance as well as psychological performance, having the will to act is one of main factors to develop performance skills in playing an instrument as a part of music education. Thus, it is critical to study the determinants of motivation of students related to their study areas. That's why this study aims to determine the effect of psychological capital on motivation for individual instrument.

Another importance of the study is that the role of psychological capital in academia is attached limited attention [5]. However, all studies highlight the importance of psychological capital on students' academic achievement and personal goals [34-39]. Moreover, psychological capital was found as a buffer to student stress [40].

In addition, there are some studies studied the relations among subfactors of both variables. For instance; individuals with higher self-efficacy have a higher intrinsic motivation [44]. According to a research on the relation between psychological capital and motivation, there is significant and positive relation between hope and extrinsic motivation [45]. Hope is one of determinants of positive and successful coping strategies [46, 47]. The persons having hope use intrinsic and extrinsic motivation resources effectively; thus keep their activeness while they achieve the goals [48]. Intrinsic motivation is a significant mediator between psychological capital of students and their study engagement [50]. In the light of discussion, we hypothesize that psychological capital significantly affects motivation for individual instrument.

Data on demographic information, psychological capital, and motivation for individual instrument were gathered through a self-reported questionnaire. The construct validity was analyzed by CFA and Cronbach Alpha coefficient was employed to test the reliability. The second-level related models for psychological capital and motivation for individual instrument were confirmed [3, 20].

Regarding psychological capital, resilience and self-efficacy have the greatest mean while hope and positivism are lower, respectively. However, all subfactors of psychological capital are over average. Considering motivation for individual instrument, motivation for achievement has the highest average whereas amotivation has the lowest mean.

Independent sample t-test and one-way analysis of variance (ANOVA) were employed in the study to investigate whether psychological capital and motivation for individual instrument of the students differ by demographic factors. Resilience and motivation for achievement differ by class. As Uluçay [55] reports that there is no significant difference among individual instrument course attitude scores according to the level of grade, it is not unusual all subfactors don't differ by class. Regarding resilience, perceptions of the freshman are significantly greater than sophomore. It is clear that first class of music education require hard working and orientation following high school need some strong state to confront problems. Regarding motivation for achievement, perceptions of the freshman are significantly greater than senior. There is a declining trend for the motivation for achievement through the first class to the last. Skill development may replace academic achievement in parallel with growing university years. In addition, psychological capital does not differ by gender. On the other side, amotivation significantly differs by gender that perceptions of female students are significantly lower than the males.

It is also found out that motivation for individual instrument does not differ by university students enrolled while all subfactors of psychological capital, except hope, significantly differ by the university. It is difficult to discuss the results according to university without additional information, in particular organizational factors. Nonetheless, fresh start of AHBVU in 2018 may be a significant factor for the students to differentiate the perceptions of resilience, self-efficacy, and positivism. On the other hand, there is a definite difference between the universities concerning the departments. The students studying at GU are music teacher candidates whereas the ones at conservatoire at AHBVU are on the way to be artists. Difference in tracks may create difference of the perceptions. Reminding government employment policy, process of music teacher is relatively easier than that of conservatoire. This may, but not limited to, strengthen the students enrolled at AHBVU.

In order to test the research hypothesis, second-level related models of psychological capital and motivation for individual instrument was used to form SEM and to run regression analysis to identify the interactions among the 
variables. Regression analysis shows that resilience significantly and positively affects motivation for achievement. There are no significant interactions among the other variables. This finding is partially in compliance with some studies in the literature [5, 42, 44-48]. However, the literature is not clear on the relation among subfactors of psychological capital and motivation for individual instrument.

Regarding the interaction between resilience and motivation for achievement, the importance of the motivation for individual instrument of the students studying at music department and its interaction with various variables is made more sense. We know that resilience means continuing for success following recoveries each time even when an individual is surrounded by negative events [18]. And skill development would lead to academic achievement; however, it would take long time and require psychical effort. Hence resilience of the students may be improved by including resilience-oriented activities in the syllabus and incenting social activities focusing resilience. Reminding that intrinsic motivation asks for enjoying and interesting design of the lesson, teachers may be innovative and creative to make the lesson more interesting to increase participation.

In addition, departments are expected to promote student activism by providing clean and safe place and supporting the students taking leadership roles displaying enthusiasm for their departments. Moreover, lessening the fear for failure and teaching the students learning how to learn may strengthen the mindsets of the students with less resilience to motivate for achievement.

The inclusion of different variables affecting the motivation of music students will bring a different perspective to the literature. In addition, when it is considered in the context of students, it can be encouraged to focus psychological capital to strengthen motivation. From this point of view, it is highly recommended that further studies focus on determinants and consequences of motivation for individual instrument and psychological capital. Moreover, demographic factors play significant role as a determinant of the variables since both variables are directly related to personality. In addition, there are differences in three dimensions of psychological capital between two university's students. Hence, future studies may design research models including demographic factors-both personal and organizational factors.

On the other hand, there are some limitations of the study. At first, the sample of the study is from the students studying at universities located in Ankara, Turkey. This limitation is threefold. One is the sample is consisted of the students, next, the students study at teaching, and last but not least, quality of life affects the motivation. That's why the findings may be bound by the sample. Second, perceptions of the students are measured in a cross-sectional design. Thus, the findings are related to the psychology for the participants at the time measured. Third, participants may answer the questionnaire as they would be instead not actually they are. Therefore, it is significant that limitations may be kept in mind while findings are generalized.

\section{REFERENCES}

[1] D. Özçelik Herdem, Opinion by Staff Violin the Motivation of Students the Education of Approach for Improvement Evaluation. Journal of Strategic Research in Social Science, 2 (4), 67-82, 2016.

[2] R. J. Sternberg, W. M. Williams, Educational Psychology. Boston, MA: Allyn \& Bacon, 2002.

[3] E. L. Deci, R. M. Ryan, The" what" and" why" of goal pursuits: Human needs and the self-determination of behavior. Psychological Inquiry, 11(4), 227-268, 2000.

[4] C. Peklaj, M. P. Levpušček, Student motivation and academic success in relation to the quality of individual and collaborative work during a course in educational psychology. 31. Association of Teacher Education in Europe (ATEE) Conference, 2006.

[5] J. A. D. Datu, R. B. King, J. P. M. Valdez, Psychological capital bolsters motivation, engagement, and achievement: Cross-sectional and longitudinal studies. The Journal of Positive Psychology, 13(3), 260-270, 2016.

[6] C. C. Manz, Self-leadership: Toward an expanded theory of self-influence processes in organizations. Academy of Management Review, 11(3), 585-600, 1986.

[7] A. Bandura, Perceived self-efficacy in cognitive development and functioning. Educational Psychologist, 28(2), 117-148, 1993.

[8] A. E. Woolfolk, Educational Psychology. Boston: Allyn and Bacon, 1993.

[9] R. C. Gardner, Language Learning motivation: the Student, the Teacher, and the Researcher, Texas Papers in Foreign Language Education, 6 (1), 1-18, 2001.

[10] R. Fisher, Teaching Children to Think. Oxford: Basil Blackwell, 1990.

[11] R. C. Gardner, W.E. Lambert, Attitudes and motivasyon in second language learning, Rowley, Mass.: New bury House Publishers, 1972.

[12] Amabile, T. M., Hill, K. G., Hennessey, B. A., \& Tighe, E. M. (1994). The Work Preference Inventory: assessing intrinsic and extrinsic motivational orientations. Journal of personality and social psychology, 66(5), 950-967, 1994.

[13] M. E. Seligman, M. Csikszentmihalyi, Positive psychology: An introduction, American Psychologist, Vol. 55, No. 1, 5-14, 2000.

[14] F. Luthans, The need for and meaning of positive organizational behavior. Journal of Organizational Behavior: The International Journal of Industrial, Occupational and Organizational Psychology and Behavior, 
23(6), 695-706, 2002.

[15] F. Luthans, K. W. Luthans, B. C. Luthans., Positive Psychological Capital: Beyond Human and Social Capital, Business Horizons, Vol. 47, Issue 1, 45-50, 2004.

[16] P. A., Linley, S., Joseph, S. Harrington, A. M. Wood, Positive psychology: Past, present, and (possible) future. The Journal of Positive Psychology: Dedicated to Furthering Research And Promoting Good Practice, 1(1), 3-16, 2006.

[17] F. Luthans, C. M. Youssef, Emerging positive organizational behavior. Journal of management, 33(3), 321-349, 2007.

[18] F. Luthans, C. M. Youssef, Human, social, and now positive psychological capital management: Investing in people for competitive advantage, Organizational Dynamics, Vol. 33, No. 2, 143-160, 2004.

[19] J. B. Avey, F. Luthans, S. M. Jensen, Psychological Capital: A Positive Resource For Combating Employee Stress And Turnover, Human Resource Management, Vol.: 48, No: 5, 677-693, 2009.

[20] F. Luthans, J. B. Avey, B. Avolio, S. Peterson, The Development and Resulting Performance Impact of Positive Psychological Capital, Human Resource Development Quarterly, Vol. 21, No. 1, 41-67, 2010.

[21] E. Diener, Subjective well-being: the science of happiness and a proposal for a national index. American Psychologist, $55,34-43,2000$.

[22] C. Peterson, The future of optimism. American Psychologist, $55,44-55,2000$.

[23] C. R. Snyder, Handbook of hope. San Diego: Academic Press, 2000

[24] M. E. P. Seligman M., Csikszentmihalyi, Positive psychology: An introduction. American Psychologist, 55(1), 5-14, 2000.

[25] F. Luthans, C. M. Y. Morgan, B. J. Avolio, Psychological Capital and Beyond, Oxford University Press, Inc., 2015.

[26] F., Luthans, C. M. Youssef, B. J. Avolio, Psychological Capital. NY: Oxford University Press, 2007.

[27] M. Seligman, Learned Optimism. NY: Knopf, 1991.

[28] C. S., Carver, M. F. Scheier, S. C. Segerstrom, Optimism. Clinical Psychology Review, 30, 879-889, 2010.

[29] C. R., Snyder, C. Harris, J. R. Anderson, S. A. Holleran, L. M. Irving, S. T. Sigmon, et. al. The wills and the ways: Development and validation of an individual-differences measure of hope. Journal of Personality and Social Psychology, 60(4), 570-585, 1991.

[30] C. R., Snyder, K. L. Rand, D. R. Sigmon, Hope theory: A member of the positive family. In C. R. Snyder \& S. Lopez (Eds.), Handbook of Positive Psychology (pp. 257-276). NY: Oxford University Press, 2002.

[31] S. Tarhan, H. Bacanl1, İlkokuldan üniversiteye umut kavramının tanımlanması üzerine nitel bir çalıșma. Eğitimde Nitel Araştırmalar Dergisi, 4(2), 86-112, 2016.

[32] Zournazi, M. Umut değişim için yeni felsefeler (çev. U. Abac1). İstanbul: Literatür, 2004.
[33] M. K. Topçu, M. Ocak, Psikolojik Sermayenin Tükenmişlik Algısı Üzerine Etkisinde İş Tatmininin Aracılık Rolü: Türkiye ve Bosna-Hersek Sağlık Çalışanları Örneği. Dokuz Eylül Üniversitesi Ulusal Yönetim ve Organizasyon Kongresi Bildiriler Kitab1, 685-690, 2012.

[34] F. Yalçın, The Effects of Psychological Capital on the Entrepreneurial Intention of University Students, Unpublished Master's Thesis, Erciyes University, Kayseri, 2018.

[35] Mercan, N. (2016). Psychological capital research for relations with career adaptability. In Global Business Research Congress (GBRC-2016) (Vol. 2, pp. 26-27). 2016

[36] E. İştar Işıklı, Üniversite Öğrencilerinde Psikolojik Sermaye: Düzce Ilinde Bir Alan Araştirmasi, EKEV Akademi Dergisi Y11: 22 Say1: 73, 333-344, 2018.

[37] E. İştar Işıklı, Sağlik Yönetimi Bölümü Öğrencilerinde Psikolojik Sermayenin Yaşam Tatmini ile Ilişkisi: Düzce Üniversitesi Örneği. Electronic Turkish Studies, 13(7), 163-174, $2018 b$.

[38] B. C. Luthans, K. W. Luthans S. M. Jensen, The impact of business school students' psychological capital on academic performance. Journal of Education for Business, 87(5), 253-259., 2012.

[39] V. Vanno, W. Kaemkate, S. Wongwanich, Relationships between Academic Performance, Perceived Group Psychological Capital, and Positive Psychological Capital of Thai Undergraduate Students, Procedia - Social and Behavioral Sciences, Volume 116, 3226-3230, 2014.

[40] L. Riolli, V. Savicki, J. Richards, Psychological capital as a buffer to student stress. Psychology, 3(12), 1202.-1207, 2012

[41] M. Kalman ve T. Gedikoğlu, İlkokul ve Ortaokul Öğretmenlerinin Psikolojik Sermayelerinin İncelenmesi, 8. Ulusal Eğitim Yönetimi Kongresi - Bildiri Özetleri, 138-140, Marmara University, İstanbul, 2013.

[42] F. Çetin, D. Aşkun, H. N. Basım, The Effects of Psychological Capital on Weekly Changing Internal Work Motivation and Related Work Performance Outcomes: A Longitudinal Analysis, Eurasian Business \& Economics Journal, Volume: S2 1-7, 2016.

[43] M. Kalman, An Implementation to Develop Middle School Teachers' Psychological Capital, Unpublished Dissertation, Gazıantep University, Gaziantep, 2017.

[44] F. Luthans, J. B. Avey, B. Avolio, S. M. Norman, Positive Psychological Capital: Measurement and Relationship with Performance and Satisfaction, Personnel psychology, 60(3), 541-572, 2007.

[45] B. Varol, The Effect of Psychological Capital on Motivation in Human Resources Management, Unpublished Master's Tehsis, Bahçeşehir University, İstanbul, 2017.

[46] B. W. Roberts, R. W. Robins, Broad dispositions, broad aspirations: The intersection of personality traits and major life goals. Personality and Social Psychology Bulletin, 26(10), 1284-1296, 2000.

[47] D. C. Orlich, No Child Left Behind: An illogical accountability model. Clearing House, 78, 6-12, 2004. 
[48] K. K. Wrobleski, C. R. Snyder, Hopeful thinking in older adults: Back to the future. Experimental Aging Research, 31(2), 217-233, 2005.

[49] Ö. Eraslan, The Investigation of the Mediator Role of Positive Views of Self, World and Future on the Relationship of Psychological Resilience with Depressive Semptoms and Life Satisfaction in University Students, Unpublished Master's Thesis, Hacettepe University, Ankara, 2014.

[50] O. L. Siu, A. B. Bakker, X. Jiang, Psychological capital among university students: Relationships with study engagement and intrinsic motivation. Journal of Happiness Studies, 15(4), 979-994, 2014.

[51] S. Doğan, M. Aslan (2016). Psikolojik Sermaye, İçsel Motivasyon ve İş Tatmini İlişkisi. Ömer Halisdemir Üniversitesi İktisadi ve İdari Bilimler Fakültesi Dergisi, 11(3), 112-125, 2018.

[52] https://www.surveysystem.com/sscalc.htm.

[53] D. Girgin, Bireysel çalgı dersi motivasyon ölçeği: geçerlik güvenirlik analizi. KÜ Kastamonu Eğitim Dergisi, 23(4), 1723-1736, 2015.

[54] C. H. Meydan, H. Şeşen. Yapısal eşitlik modellemesi AMOS uygulamaları. Detay Publishing, 2011.

[55] T. Uluçay, Determining the Attitudes of Undergraduate Students Having Vocational Music Education towards Individual Instrument Course According to Different Variables. Universal Journal of Educational Research, 5(10), 1759-1763, 2017. 